\title{
Sustainable use of resources in plant factories with artificial lighting (PFALs)
}

\author{
F. Orsini ${ }^{1}$, G. Pennisi ${ }^{1}$, F. Zulfiqar ${ }^{2}$ and G. Gianquinto ${ }^{1}$ \\ ${ }^{1}$ Research Centre on Urban Environment for Agriculture and Biodiversity, Agricultural Sciences Department, Alma Mater \\ Studiorum - University of Bologna, Bologna, Italy \\ ${ }^{2}$ Institute of Horticultural Sciences, Faculty of Agriculture, University of Agriculture Faisalabad, Pakistan
}

\section{Summary}

Plant Factories with Artificial Lighting (PFALs) are spreading due to the claimed efficiency in natural resources use, although at the cost of higher energy needs as compared with more traditional food systems. In recent years, research literature on PFAL technological features and management protocols has bloomed, mainly targeting innovation in lighting technologies, growing systems and environmental control units. To date, however, a comprehensive analysis of resource use and environmental impacts associated with PFAL systems is lacking. The present review paper aims at providing valuable insights on PFAL sustainability and compare their applications against current technologies and food systems with a special focus on resource use efficiency.

\section{Keywords}

vertical farming, indoor farms, vertical farms with artificial lighting (VFAL), environmental assessment, water use efficiency (WUE), land surface use efficiency (SUE), energy use efficiency (EUE), life cycle analysis (LCA), environmental impact, sustainability

\section{Introduction}

Main challenges of modern agriculture are associated with growing scarcity in natural resources availability. The growth of global population from 2.5 billion in 1950 to 7.7 billion in 2019, and the estimation of 11.2 billion by the end of the century (Pison, 2019) is resulting in two connected phenomena. Firstly, as reported by Li et al. (2019), global urban area is estimated to increase roughly 40 to $70 \%$ until 2050 (relative to the base year of 2013) to accommodate a growing urban population, leading to a decrease of agricultural land availability (to date at 0.7 ha per capita) (Chen et al., 2018). Secondly, an increase of global food demand (estimated in $+60 \%$ for cropland and $+70 \%$ for dairy farming, to be met by 2050) (Alexandratos and Bruinsma, 2012) is expected. These trends will increase the pressure on global freshwater reservoirs, already affected by climate change and by the forecasted fluctuations in the precipitation patterns (Patle et al., 2019). Furthermore, excess mineral fertilization is raising concerns on the overall sustainability of current agricultural systems. Since the green revolution, the indiscriminate use of nitrogen fertilizers has resulted in environmental pollution, including eutrophication, acidification of water, and emission of $\mathrm{N}_{2} \mathrm{O}$ into the atmosphere (Lal, 2018) increasing greenhouse gases emissions at an average rate of

\section{Significance of this study}

What is already known on this subject?

- PFALs are spreading due to the claimed efficiency in natural resources use, although at the cost of higher energy needs.

\section{What are the new findings?}

- Recent literature addressed the definition of resource use efficiency and environmental assessment of PFALs.

What is the expected impact on horticulture?

- To provide valuable insights on PFAL sustainability and compare their applications against current technologies also in terms of resource use efficiency.

3.9\% per year from 1961 to 2010 (IPCC, 2014). Phosphorus is a non-renewable resource extracted from phosphate rocks or eventually recycled from waste water, which is essential for plants growth. Not only the production of fertilizers from rock phosphate involves significant carbon emissions, radioactive by-products and heavy metal pollutants, but also a number of studies reported global phosphate reserves will be depleted in 50-100 years (Cordell et al., 2009). Similar concerns on the reduced availability of other nutrients have also arisen, such as with regard to potassium (Sardans and Peñuelas, 2015).

In this complex context, innovative urban plant production systems are gaining increasing popularity. In the last decade, the academic debate on vertical farms resulted in authors insisting on the great potential of greened skyscrapers as the ultimate solution for vertical farming (Despommier, 2009), versus the transformation of existing vacant and unproductive spaces of the urban fabric into hydroponic farms, toward the so-called concept of Zero-Acreage Farming or Z-Farming (Thomaier et al., 2015). It is the case of vegetables produced by residents on the rooftop of a social housing building in the city of Bologna (Orsini et al., 2014), the integration of greenhouses on the rooftop of public or private buildings in Barcelona (Sanyè-Mengual et al., 2015) or The Hague (Stadler et al., 2015), or the growing phenomenon of Plant Factories with Artificial Lighting (PFALs). PFALs, also called indoor farms or Vertical Farms with Artificial Lighting (VFALs), are closed plant production systems where environmental factors (e.g., temperature, humidity, light, $\mathrm{CO}_{2}$ ) are controlled, minimizing the interactions with the external climate. Existing examples may be found for instance 
in Japan (Spread Co., Ltd., http://www.spread.co.jp/en/, or Mirai Co., Ltd., http://miraigroup.jp/en/), United States (AeroFarms $^{\circledR}$, https://aerofarms.com/) or the Netherlands (GROWx, https://www.growx.co/). As reported by Kozai and Niu (2016), a PFAL is basically constituted by a well-insulated and nearly airtight cultivation area with opaque walls, a cultivation system equipped with artificial light, a climatic control system, a $\mathrm{CO}_{2}$ supply unit, and a nutrient solution delivery unit. Several researches (Kozai and Niu, 2016; Kozai, 2019; Pennisi et al., 2019a) have highlighted the advantages of PFAL systems principally related to (a) yearly stable production achieved by controlling the environmental factors, (b) improved quality of the food produced in a controlled environment (e.g., reduction on the use of pesticides), (c) reduced distance from consumption centers (e.g., fresher food), and (d) improved resources use efficiency (e.g., by exploring the vertical dimension, yield per unit surface are increased, and thanks to hydroponics, water use is reduced). On the other hand, challenges in PFALs include energy costs and initial setup costs (Song et al., 2019) which can be higher than in more conventional food production systems. Moreover, for what concerns the use of agricultural input, while the adoption of closed environments and hydroponics may limit the possibility to benefit from minerals already present in the soil or the functional biodiversity encountered in conventional agriculture, the adoption of closed-loop systems and the insulation from external environments in PFALs were suggested to generally reduce the relative input use associated with crop production (Graamans et al., 2018; Kozai, 2013).

The present review paper aims at defining the role played by PFAL technologies and management strategies on the overall food system sustainability, building on most recent research literature. Accordingly, the role on energy needs played by artificial lighting, the plant cultivation systems used and the technologies adopted for climate control will be defined. Strategies for improved resources use efficiency - including water use efficiency (WUE, expressed as grams of fresh weight per liter of water consumed, g FW $\mathrm{L}^{-1} \mathrm{H}_{2} \mathrm{O}$ ), land surface use efficiency (SUE, expressed as daily productivity per unit of land used, $\mathrm{g} \mathrm{m}^{-2} \mathrm{~d}^{-1}$ ) and energy use efficiency (EUE, notably the yield per unit of electricity consumed, $\mathrm{g} \mathrm{kWh}^{-1}$ ) - will be described. Finally, the review will bring together evidences on environmental assessment of crop production and identified strategies for reduced environmental contamination.

\section{Sustainable PFAL technologies}

\section{LED lighting}

PFAL systems are a world-changing innovation for modern time relying on various inputs, among which sufficient light provision is the most important factor for sustaining plant growth and development. As reported by Kikuchi et al. (2018), vertical farming systems can be divided into two categories based on the light source for fulfilling the photosynthesis and photoperiod requirements of plants: those operating with sunlight (plant factories with sunlight, PFSLs) and the already mentioned PFALs. In PFALs, electric lighting is used for simulating solar radiation over a photoperiod of generally $16 \mathrm{~h} \mathrm{~d}^{-1}$ (Kozai et al., 2016). Furthermore, also in the case of PFSLs, supplementary artificial lighting is commonly required to compensate for the lower exposure to direct sunlight in the interior areas of the structure or in the case of areas shaded by nearby buildings (Kozai and Niu,
2016). Overall, the need for supplying PFALs with artificial light is raising concerns on the environmental and economic sustainability of the system (Kalantari et al., 2018) because electricity results in a major share of production costs (Yokoyama, 2019).

In the last decades, the technological advances on light emitting diodes (LEDs) resulted in highly versatile and energetically efficient lighting systems for plant cultivation $(\mathrm{Xu}, 2019)$. As a consequence, LED application in the horticultural sector has rapidly grown, especially for controlled environment production systems (Bantis et al., 2018), replacing more traditional technologies (e.g., fluorescent lights in growth chambers and high pressure sodium - HPS - in greenhouses). A further lighting technology that in the coming future may gain relevance is represented by plasma-lighting, whose applicability has been preliminarily suggested for supplementary lighting in greenhouses or sole radiation source in PFALs (Park et al., 2018).

It is a well-documented phenomenon that not all regions of light spectrum have the same efficiency in enhancing the photosynthetic process of plants (Folta and Maruhnich, 2007). For instance, lettuce leaves were reported to absorb $90 \%$ of light from red (600-700 nm) and blue (400-500 nm) regions of the photosynthetically active radiation (Terashima et al., 2009). In indoor conditions, where it is possible to give plants the best light recipe for growth and development, LEDs provide the great opportunity to fulfill the light requirements at any cultivation stage, thanks to their capability to emit light in narrow bandwidths (Xu, 2019). Furthermore, due to their easy adjustability, LEDs lighting systems enable to modulate the quality, intensity and photoperiod of the emitted radiation, leading to an optimization of plants growth in terms of yield and quality (Fukuda, 2019). Accordingly, several researches on the application of LED technology for indoor plant cultivation focused on the study of the effect of red (R) and blue (B) light on growth, morphology and physiological responses of plants or toward the identification of the optimal RB ratio within the spectrum (Naznin et al., 2016; Wang et al., 2016; Chen et al., 2019; Pennisi et al., 2019b; Azad et al., 2020). Furthermore, recently, also other spectral regions have gained increasing attention. Green light (500$600 \mathrm{~nm}$ ) has been reported to increase carbon assimilation and likely plant yield, thanks to the ability to penetrate in the lower part of the canopy and in the folded layers of leaves (Smith et al., 2017) and consistently increase their chlorophyll and ascorbic acid contents (Saengtharatip et al., 2020). In several researches (Park and Runkle, 2017; Kalaitzoglou et al., 2019), the additional far red light ( $>700 \mathrm{~nm}$ ) was found to modify the structure and morphology of the plant, leading to an increase in the intercepted light and therefore in net photosynthesis. However, when far red light supply was prolonged, alterations in plant photo-morphogenesis could result in reducing tolerance to diseases, for instance against Botrytis cinerea, as observed in both Arabidopsis (Cerrudo et al., 2013) and tomato (Ji et al., 2019). Furthermore, the light supply within the ultraviolet (UV, $<400 \mathrm{~nm}$ ) spectrum was preliminarily reported to improve the nutritional quality, e.g., in lettuce (Li and Kubota, 2009), tomato (Wang et al., 2000) and pea (Liu and Yang, 2012).

As a general rule, plant responses to changes in light-related parameters are species and/or cultivar dependent and could also be influenced by the environmental conditions (e.g., air temperature and heat sum, humidity, $\mathrm{CO}_{2}$ concentration) (Ouzounis et al., 2015). Beside the advantages associated with the possibilities for manipulating the spectral 
TABLE 1. Examples of possible strategies for improving sustainability of PFALs.

\begin{tabular}{|c|c|c|}
\hline \multicolumn{2}{|c|}{ Solutions to improve resources use efficiency in PFAL } & \multirow{2}{*}{$\begin{array}{l}\text { References } \\
\text { Li et al., } 2014\end{array}$} \\
\hline Lamps & Use of movable lamps to reduce initial investment costs & \\
\hline & Different lamps typologies influence EUE & $\begin{array}{l}\text { Kong et al., 2019; Zhang et al., 2018; } \\
\text { Hernandez et al., } 2020\end{array}$ \\
\hline & Higher diodes PPE increase EUE & Kusuma et al., 2020 \\
\hline & Use of zoom lens increases EUE & Li et al., 2016 \\
\hline \multirow[t]{6}{*}{ Spectral composition } & RB $\geq 3$ increase WUE, SUE, EUE in basil & Pennisi et al., 2019a, c \\
\hline & $R B \geq 3$ increase WUE, SUE, EUE in lettuce & Pennisi et al., 2019b, c \\
\hline & $R B \geq 2$ increase WUE and EUE in rocket & Pennisi et al., 2019c \\
\hline & $\mathrm{RB} \geq 2$ increase WUE and EUE in chicory & Pennisi et al., 2019c \\
\hline & $\mathrm{RB}=2.7$ increase EUE in lettuce & Yan et al., 2019 \\
\hline & $\mathrm{RB}=4$ increase EUE in lettuce & Kong et al., 2019 \\
\hline Light intensity & Increased light intensities reduce EUE & Yan et al., 2019 \\
\hline \multirow[t]{3}{*}{ Growing system } & $\begin{array}{l}\text { Vertical columns increase SUE as compared with horizontal systems, } \\
\text { but decrease plant size }\end{array}$ & Touliatos et al., 2016 \\
\hline & Adaptive plant spacing increase SUE & Ioslovich and Gutman, 2000 \\
\hline & Aeroponics increase WUE & Alshrouf, 2017 \\
\hline \multirow[t]{5}{*}{ Climate management } & $\begin{array}{l}\text { Dehumidification of water from internal air allows to recover water transpired } \\
\text { by plants and increase WUE }\end{array}$ & Kozai, 2013 \\
\hline & Use of co-generation system increase EUE as compared with heat pumps & Yokoyama, 2019 \\
\hline & Changes in insulation (U-value) and albedo of façades affect EUE & Graamans et al., 2020 \\
\hline & Use of fiber-optic solar energy transmission system increase EUE & Qiao and Zhang, 2014 \\
\hline & $\begin{array}{l}\text { Use of solar collectors and optical fibers to integrate solar radiation in PFALs } \\
\text { for increased EUE }\end{array}$ & Yalçın and Ertürk, 2020 \\
\hline
\end{tabular}

composition, the small size, physical robustness, and scarce radiant heat emission have also been reported as advantages of LED technology as compared to more conventional lighting systems (Janssen et al., 2019), enabling their installation even very close to the plants in a multi-layer farming system (Stutte, 2015).

On the other hand, the most claimed weakness of LED lighting technology is the initial cost (Wu et al., 2019), which resulted 5 to 10 times higher than HPS lamps (Nelson and Bugbee, 2014). Accordingly, among the strategies for reducing installation costs associated with lamp purchase, the adoption of movable lighting systems (Li et al., 2014) allowed to integrate 24 hours shifts in the usage of the lamps (Table 1). Furthermore, as compared to more traditional lighting systems, the capital investments may be counterbalanced by the longer lifespan and greater efficacy of LEDs. It is however to be remarked that the definition of lifespan differs depending on the lighting source (Richter et al., 2019). For conventional lighting systems, the average rated life is commonly used, and is defined in hours when $50 \%$ of a large group of lamps has failed. The average rated life is approximately $9,000 \mathrm{~h}$ for fluorescent lamps and at least $24,000 \mathrm{~h}$ for HPS (Wu et al., 2019). The lifespan of LED lamps is instead defined as the operating time between the start of their use and the moment when only $50 \%$ of the total number of lamps survive or when the average lumen maintenance of the batch falls below 70\% (L70), whichever occurs first (Song et al., 2013). LED-chip industries estimate that the L70 of a LED ranges between $30,000 \mathrm{~h}$ and $50,000 \mathrm{~h}$, depending on the operating temperature of the diodes (Cree, 2017; Philips Lumileds Lighting, 2017). The issue however is that a LED lamp is a set of subcomponents of different materials, which make the determination of the lamps lifespan trickier as compared to traditional lighting systems (Wu et al., 2019). With regard to the transformation of electricity into light energy, efficacy (expressed in $\mu \mathrm{mol} \mathrm{J}^{-1}$ ) is acknowledged as the best unit measure to compare different lighting systems with measured values of about $0.9 \mu \mathrm{mol} \mathrm{J}^{-1}$ for fluorescent lamps and between 0.9 and $1.7 \mu \mathrm{mol} \mathrm{J}{ }^{-1}$ for HPS lamps (Bugbee, 2017). The LED diodes efficacy is claimed to theoretically reach 4.6-5.1 $\mu \mathrm{mol} \mathrm{J}^{-1}$ (Wu et al., 2019), even if the highest reported efficacy for LED luminaries is to date $2.5 \mu \mathrm{mol} \mathrm{J}^{-1}$ (Bugbee, 2017), resulting in a $47 \%$ of electricity saving if compared with the best reported efficacy for HPS lamps. More recently, it was estimated that (depending on the differences observed among diodes of different colors), efficacy limits for RB LED lamps would be of around $4.1 \mu \mathrm{mol} \mathrm{J^{-1 }}$, these values being reduced by about $10 \%$ when optical protection from water and high humidity is integrated (Kusuma et al., 2020).

\section{Hydroponics and aquaponics}

The commonly adopted cultivation method in PFALs is soilless culture (Son et al., 2020), defined as any method of growing plants in absence of soil, in which plant nutrients are dissolved in and supplied with irrigation water and the resultant solution is referred to as "nutrient solution" (Savvas et al., 2013). Soilless culture is usually used in PFALs since it enables the grower to automate and optimize irrigation and fertilization management, to save labor, to improve product quality (Savvas et al., 2013), and to fit multilayer cultivation (Wada, 2019). Soilless systems can be classified according to the type of root support into substrate crops (artificial, mineral or organic or a mix of these) and crops without substrate or hydroponics, in which the root system is either immersed in a nutrient solution (e.g., Nutrient Film Technique or NFT, floating hydroponics, etc.) or simply free in the air and suspended in a fine mist of nutrient solution applied continuously or intermittently (aeroponic systems). Soil- 
less systems are also divided according to the management of the drained nutrient solution into open- and closed-loop systems. In open-loop systems the drained nutrient solution is thrown out of the system while in closed-loop systems it is recovered, replenished and recycled (Savvas et al., 2013). Among these technological solutions, deep flow technique (DFT), ebb-and-flow systems, nutrient film technique (NFT) and aeroponics are the most widespread systems adopted in PFALs (Son et al., 2020). Furthermore, aeroponics is claimed to be the best option in terms of water saving (Lakhiar et al., 2018) (Table 1).

In order to enhance the water and nutrients use efficiency of the system and eliminate waste, closed-loop systems are commonly adopted in PFALs (Son et al., 2020). Before being recirculated to the plants, in order to avoid nutrients imbalance, the drained solution passes through a control loop to be analyzed and adjusted based on online measurements of pH and electrical conductivity (EC), which provides information on the total concentration of the nutrient solution but not on the concentrations of individual ions, thus not allowing individual real-time correction of each nutrient (Jung et al., 2019). This limitation may be overcome by using ion sensors (e.g., electrode-type ion sensors, ion-sensitive field-effect transistor ISFET-type chemical sensors), which however may suffer from high maintenance costs as well as lower durability and stability as compared with EC-based control methods (Rius-Ruiz et al., 2014). Among available sensors, most efficient ones (allowing monitoring of $\mathrm{NO}_{3}, \mathrm{~K}$ and Ca ion components) are the ion-selective electrodes (ISE), characterized by simple methodology, rapid response, direct measurement of the analyte and low cost (Cho et al., 2017). The real-time monitoring of nutrients concentration, water level, $\mathrm{pH}, \mathrm{EC}$, temperature and flow of the nutrient solution can be bundled using the Internet of Things (IoT), which allows for intelligently controlling the hydroponic system, employing deep neural networks and enabling automation (Maldonado et al., 2019).

To further close the nutrient cycles in PFALs, it has been suggested that hydroponics can be coupled with an aquaculture system, obtaining an aquaponics PFAL (Endo, 2019), where fish and vegetables are contemporarily produced. In aquaponics, by-products of aquaculture (e.g., fish dejections and decomposed fish feed) become the inputs for plants development in the hydroponic unit thanks to the action of nitrifying bacteria that transform the ammonia produced by the fish to nitrates easily absorbed by roots (Calone et al., 2019). To close the loop, plants filter and clean the water that can return to the fish tank. Palm et al. (2018) highlighted aquaculture system can furnish the majority of nutrients ( $>50 \%$ ) for plants growth if coupled with a hydroponic unit, resulting in great economic and environmental savings in terms of chemical nutrients. On the other hand, however, the water coming from aquaculture units may need the integration of ammonium, potassium, iron, manganese and zinc to reach an optimal composition for plants growth (Calone et al., 2019; Endo, 2019). Plants, fish and bacteria growth in aquaponics is principally affected by water-related parameters (e.g., temperature, $\mathrm{pH}$, and dissolved oxygen - DO), therein when coupling aquaculture and hydroponics, a compromise should be found between ideal parameters ranges (Goddek et al., 2015; Thorarinsdottir, 2015). Other challenges of aquaponics are the selection of fishes that tolerate a wide range of nutrients, $\mathrm{pH}$ and temperature and the identification of the optimal ratio between fish and plants to get the right balance between fish nutrient production and plant uptake in the sys- tem (Goddek et al., 2015). Rakocy et al. (2012) developed an index called Feeding Rate Ratio (FRR) which is the amount of feed per day per square meter of plant varieties for linking the plant growing area requirement with the daily fish feed input. As a rule of thumb, a value between 60 and $100 \mathrm{~g}$ day $^{-1} \mathrm{~m}^{-2}$ has been recommended for leafy-greens growing on raft hydroponic systems, but FRR also depends on the total water volume, water exchange rate, nutrient levels in the water source, speed of solids removal, plant typology, plant culture method (e.g., batch culture or staggered production system), and the methods for fish rearing (e.g., sequential rearing, stock splitting or multiple rearing units). Indeed, integrating a recirculating aquaculture system with hydroponics in a PFAL enables a more stable production planning as compared to other types of aquaponics systems because the plant and fish growing units can be controlled and their environment stabilized (Endo, 2019).

\section{Environmental and climatic control systems}

In PFALs, microclimate management is fundamental to guarantee a proper plant development. Due to the airtight conditions of the growing environment, continuous dehumidification is required to avoid relative humidity level increases for evapotranspiration from plant canopy (Rabbi et al., 2019), which can also result in higher severity of physiological disorders (e.g., tipburn) (Kuronuma et al., 2018). At the same time, air humidity generated by plant transpiration should be saved and reintroduced into the system in order to increase WUE (Kozai, 2019) (Table 1). Commonly adopted strategies for dehumidification in PFAL use heat pumps (operating in thermodynamic closed cycle with a refrigerant at temperatures below the dew point of the air) or adsorption methods (using a desiccant material which needs to be regenerated using thermal energy) (Rabbi et al., 2019). Generally, outdoor ventilation is not encouraged due to the reduction of $\mathrm{CO}_{2}$ use efficiency and the potential introduction of pests and pathogens from outside (Kozai, 2013). Indeed, in an airtight environment with high planting density, $\mathrm{CO}_{2}$ concentration can drop below outdoor values, limiting photosynthesis and plant growth (Gómez et al., 2019). Therefore, $\mathrm{CO}_{2}$ enrichment systems are commonly used to increase $\mathrm{CO}_{2}$ concentration in both greenhouses and PFALs, usually up to $800 \mu \mathrm{mol} \mathrm{mol}{ }^{-1}$, a cost-effective threshold enabling to promote both photosynthesis and plant growth (Gómez et al., 2019).

Plant development is also influenced by air temperature, therefore a uniform spatial air temperature distribution in the PFAL cultivation room is needed to obtain homogenous plant growth (Kozai et al., 2016). Artificial lighting systems may produce heat which should be removed by the growing environment through the use of heat pumps to maintain an optimal air temperature (Wang et al., 2016). Furthermore, spatial uniformity of air temperature can be obtained thanks to homogenous air recirculation inside the PFAL through the use of air fans (Kozai et al., 2016). Both heat pumps and air fans need electricity-energy, whose costs, summed with those consumed by the artificial lighting system, were estimated to account for around the $30 \%$ of the total operation costs of a PFAL (Wang et al., 2016). Indeed, thanks to technological advances, the electricity costs contribution were more recently estimated to be around $21 \%$ of the total running costs (Kozai et al., 2019). Consistently, in a pilot experimental PFAL producing 5,000 head of lettuce per year, the amount of energy used for air conditioning system accounted for $30 \%$ of the total energy requirements (Yokoyama, 2019). 


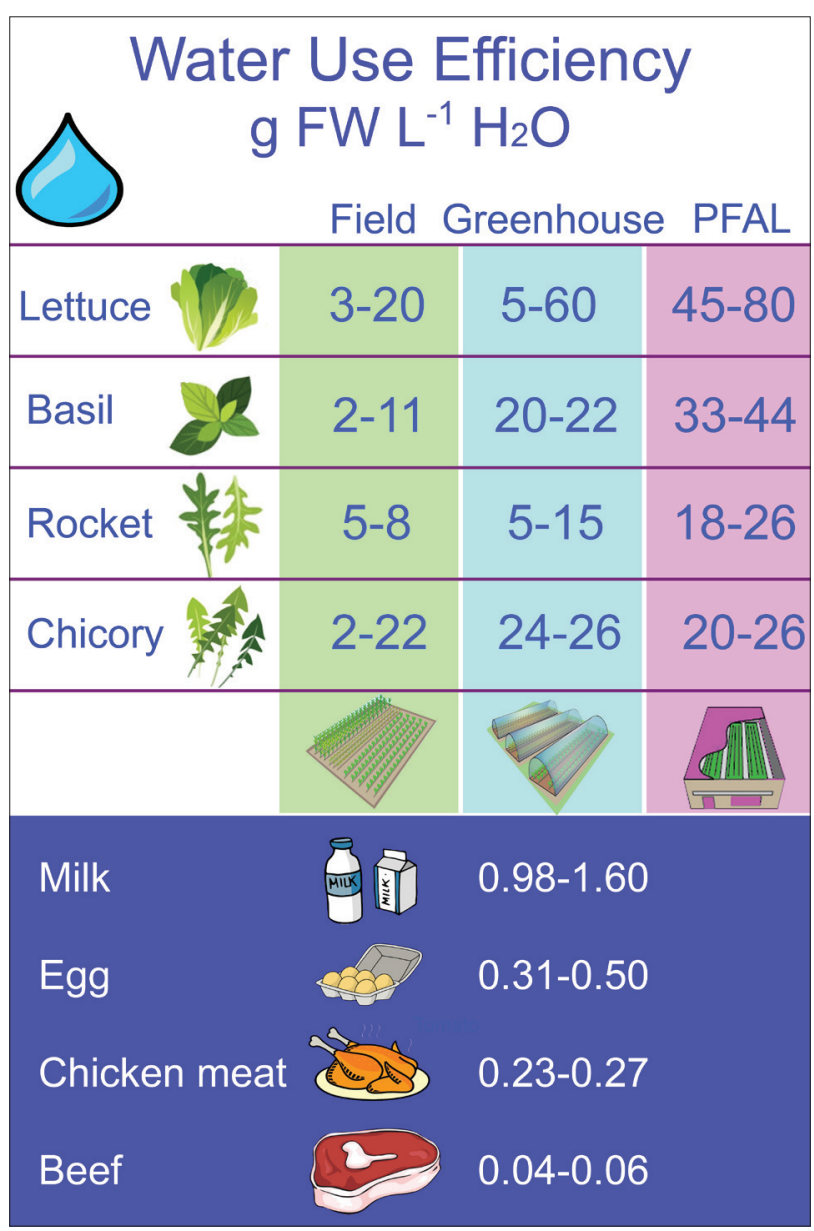

FiguRE 1. Water use efficiency (WUE) of selected food products in response to the cropping system. Values are based on literature on lettuce (Barbosa et al., 2015; Maraseni et al., 2012; Van Ginkel et al., 2017; Pennisi et al., 2019b, c), basil (Palada et al., 1995; Ekren et al., 2012; Montesano et al., 2018; Pennisi et al., 2019a, c; Kalamartzis, 2020), rocket (Demirel et al., 2014; Schiattone et al., 2017; Pennisi et al., 2019c) and chicory (Patel et al., 2000; Moosavi et al., 2012; Bortolini et al., 2016; Atzori, 2019; Bortolini and Tolomio, 2019; Pennisi et al., 2019c). Values from PFAL do not consider dehumidification from atmospheric humidity and recirculation. Values from comparison from animal based products are obtained from Mekonnen et al. $(2012,2019)$ and Nguyen et al. (2010).

In this context, the reduction of energy used for environmental conditions management can be helpful to reduce the operational costs (Wang et al., 2016). In PFALs, motor-driven heat pumps are commonly used, which use electricity-energy to convert heat with low temperature in heat with high temperature for warming-up the environment (or vice versa, whenever cooling is needed) (Yokoyama, 2019). Common heat pumps can be substituted with co-generation equipment (where also electricity is produced by utilizing the difference between heats with high and low temperature) or tri-generation equipment (where not only electricity but also $\mathrm{CO}_{2}$ included in the exhaust gas generated from the heat engine can be utilized to promote plant growth). Yokoyama (2019) reported that by substituting the heat pump with a cogeneration equipment, a $30 \%$ reduction in a PFAL energy consumption can be achieved (Table 1).

\section{Resources use efficiency}

\section{Water use efficiency (WUE)}

Today, the agricultural sector utilizes almost $70 \%$ of world fresh water (Pastor et al., 2019). Accordingly, there is a tremendous need to find sustainable and environmentally friendly solutions to maintain food production with minimal usage of water. From this perspective, PFALs possess a huge potential to enhance WUE of the food production systems (Graamans et al., 2018; Kozai and Niu, 2016), thanks to the use of soilless technologies and the improved photosynthetic efficiency under the stable lighting and climatic conditions provided by the indoor environment. When mixed animal-plant production is achieved (e.g., in aquaponics), the possibility to recycle water also into the fish production unit will result in further water saving, with a reduction in water requirements by $95-99 \%$ as compared with those commonly found in traditional aquaculture systems (Dalsgaard et al., 2013).

Reported WUE values for lettuce reached $80 \mathrm{~g} \mathrm{FW} \mathrm{L}^{-1} \mathrm{H}_{2} \mathrm{O}$ in plants grown in insulated growth chambers and supplied with a red and blue LED spectrum (Pennisi et al., 2019b), an impressive value when compared with existing literature on traditional greenhouses (5-60 g FW L $\mathrm{H}^{-1} \mathrm{H}_{2} \mathrm{O}$ ) (Barbosa et al., 2015; Van Ginkel et al., 2017) or open field (3-20 g FW L $^{-1}$ $\mathrm{H}_{2} \mathrm{O}$ ) (Maraseni et al., 2012; Barbosa et al., 2015) cultivation (Figure 1). Similarly, WUE of basil in insulated growth chambers supplied with red and blue light were shown to reach up to about $44 \mathrm{~g} \mathrm{FW} \mathrm{L}^{-1} \mathrm{H}_{2} \mathrm{O}$ (Pennisi et al., 2019a), as compared with lower values observed in greenhouse (20-22 $\mathrm{g} \mathrm{FW} \mathrm{L}^{-1}$ $\mathrm{H}_{2} \mathrm{O}$ ) (Montesano et al., 2018) and open field (2-11 $\mathrm{g} \mathrm{FW} \mathrm{L}^{-1}$ $\mathrm{H}_{2} \mathrm{O}$ ) (Palada et al., 1995; Ekren et al., 2000; Kalamartzis, 2020) (Figure 1). Cultivation in growth chamber with artificial light also affected WUE of rocket and chicory plants, allowing both crops to reach values up to 26 g FW L-1 $\mathrm{H}_{2} \mathrm{O}$ (Pennisi et al., 2019c). In rocket, the value is impressive as compared to previously observed WUE for greenhouse and open-field cultivation ranging respectively 5 to $15 \mathrm{~g} \mathrm{FW} \mathrm{L}^{-1}$ $\mathrm{H}_{2} \mathrm{O}$ (Schiattone et al., 2017) and 5 to $8 \mathrm{~g} \mathrm{FW} \mathrm{L}^{-1} \mathrm{H}_{2} \mathrm{O}$ (Demirel et al., 2014) (Figure 1). On the other hand, in chicory the benefits associated with the indoor environment were lower. Accordingly, existing literature reports values ranging between 24 and 26 g FW L $^{-1} \mathrm{H}_{2} \mathrm{O}$ (Atzori et al., 2019) and between 2 and $22 \mathrm{~g} \mathrm{FW} \mathrm{L}^{-1} \mathrm{H}_{2} \mathrm{O}$ (Patel et al., 2000; Moosavi et al., 2012; Bortolini et al., 2016; Bortolini and Tolomio, 2019), for chicory in greenhouse and open field cultivation, respectively (Figure 1). Looking at the overall water footprint of food production, these values turn out to be highly valuable, also considering that animal based products (e.g., milk, egg, chicken meat and beef) present WUE values that are generally as low as 0.04 to $1.6 \mathrm{~g} \mathrm{FW} \mathrm{L}^{-1} \mathrm{H}_{2} \mathrm{O}$ (Nguyen et al., 2010; Mekonnen et al., 2012, 2019) (Figure 1). Furthermore, in aquaponics, it is estimated that water use efficiency may reach up to $10 \mathrm{~g}$ of harvested fish $\mathrm{L}^{-1} \mathrm{H}_{2} \mathrm{O}$ (Goddek et al., 2015), an impressive value as compared against other animal products (Figure 1).

Light spectral properties were also shown to alter plant water use through modification of stomatal morphology and behavior in cucumber (Hogewoning et al., 2010), lettuce (Pennisi et al., 2019b) and basil (Pennisi et al., 2019a) (Table 1). Under predominant blue light in a red:blue ratio, for instance, stomatal conductance was increased, but overall photosynthetic efficiency decreased, as compared with a spectrum where red light was predominant (Pennisi et al., 2019a). Accordingly, in lettuce, WUE was successfully increased by $63 \%$ when modifying the relative spectral ratio of 


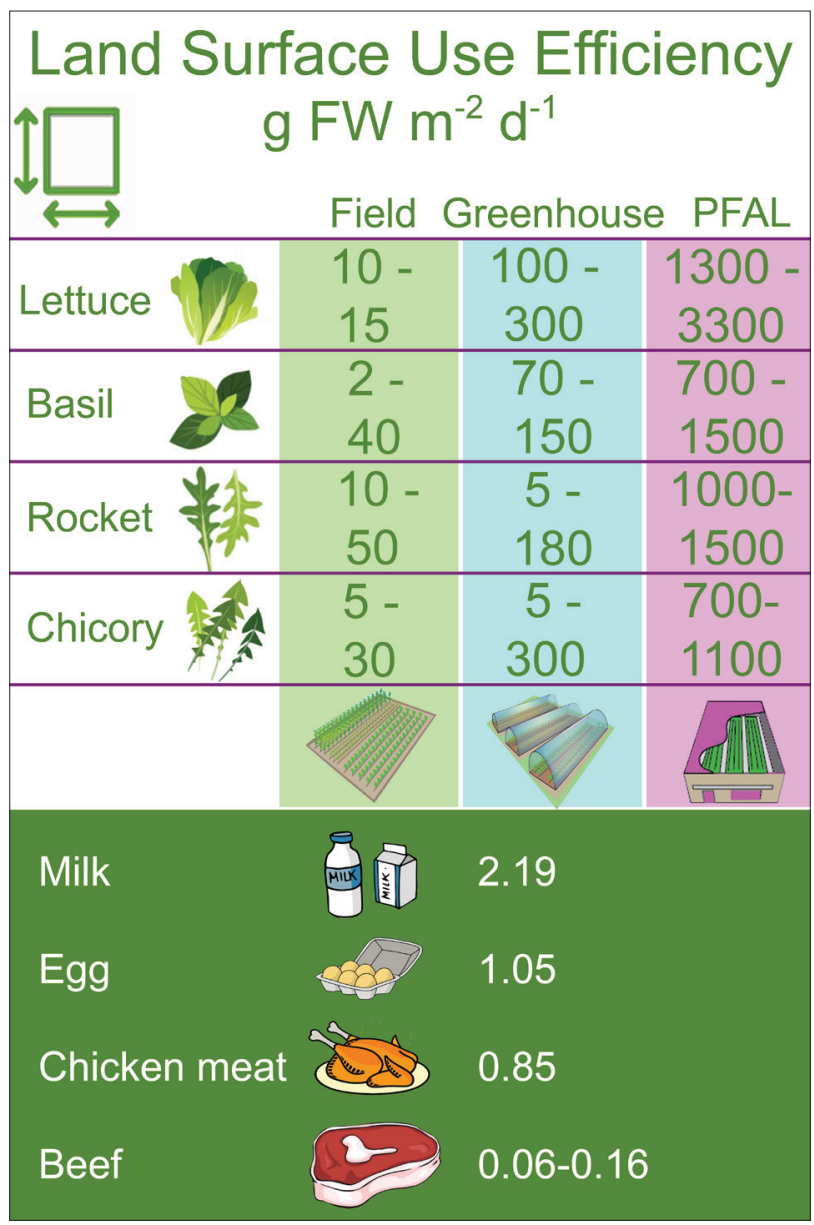

FiguRE 2. Surface use efficiency (SUE) of selected food products in response to the cropping system. Values are based on literature on lettuce (Barbosa et al., 2015; Kozai, 2019; Kozai et al., 2019; Miceli et al., 2019; Pennisi et al., 2019b, c), basil (Palada et al., 1995; Ekren et al., 2012; Saha et al., 2016; Montesano et al., 2018; Pennisi et al., 2019a, c; Kalamartzis et al., 2020), rocket (Nicola et al., 2003, 2005; Fontana and Nicola, 2009; Cantore et al., 2012; Demirel et al., 2014; Schiattone et al., 2017, 2018; Mahmoud and Taha, 2018; Miceli et al., 2019; Pennisi et al., 2019c) and chicory (Pimpini and Gianquinto, 1987; Gianquinto and Pimpini, 1989; Bortolini et al., 2016; D'Imperio et al., 2018; Bortolini and Tolomio, 2019; Pennisi et al., 2019c). Values from comparison from animal based products are obtained from Mekonnen et al. (2012, 2019) and Nguyen et al. (2010).

red and blue from $\mathrm{RB}=0.5$ to $\mathrm{RB}=3$, while it decreased again at $\mathrm{RB}=4$ (Pennisi et al., 2019c). Similarly, the most elevate WUE values were observed for $\mathrm{RB} \geq 2$ in basil $(+41 \%$ from $\mathrm{RB}=0.5)$, chicory $(+21 \%$ from $\mathrm{RB}=0.5)$ and rocket $(+26 \%$ from $\mathrm{RB}=0.5$ ) (Pennisi et al., 2019c).

Although literature is limited on crop-specific WUE values in running PFALs, the figures presented above are likely to increase due to the recovery and re-circulation of transpired water (Kozai, 2013) (Table 1). This was confirmed in a PFAL where constant air temperature $\left(30^{\circ} \mathrm{C}\right)$ and relative humidity $(80 \%)$ were maintained and water use was monitored for 14 days (Ohyama et al., 2000). It appeared that while $17 \%$ of water would be used by plants, only $7 \%$ was lost through ventilation and up to $76 \%$ could be recovered through air dehumidification (Ohyama et al., 2000), allowing its reuse for plant irrigation (Kozai and Niu, 2016). Accord- ingly, estimates for a total water requirement of $1 \mathrm{~L}$ per each $\mathrm{kg}$ of fresh lettuce produced were advanced for plant cultivation in PFALs (Benis and Ferrao, 2018; Kikuchi et al., 2018; Graamans et al., 2018; Avgoustaki and Xydis, 2020).

\section{Land surface use efficiency (SUE)}

In the foreseen scenario of growing population and urbanization, increasing land surface use efficiency (SUE) of urban farming systems is needed (Lambin and Meyfroidt, 2011). The adoption of soilless systems was shown to increase productivity of cultivated land as compared with traditional on-soil cultivation. Accordingly, Barbosa et al. (2015) reported for hydroponically grown lettuce, a SUE increase by 10-12 folds as compared with conventional production system in Arizona. Besides, PFALs possess the potential to provide further increases in productivity per unit area by adopting multiple plant cultivation tiers (Al-Kodmany, 2018). With reference to the growing solutions adopted, vertical growing towers were suggested as a strategy to increase crop yield per grown surface (Liu et al., 2004). However, these growing systems were also lately associated with smaller plant size as compared with horizontal hydroponics (Touliatos et al., 2016), therein suggesting that cultivation in PFALs should be conducted through vertically stacked horizontal trays. When considering a PFAL environment with 10 stacked cultivation layers, estimations of SUE were also provided (Kozai, 2019; Kozai et al., 2019; Pennisi et al., 2019a, b), suggesting that the enhanced yield and number of plants per unit surface in PFALs would result in SUE up to 3,300 and 1,500 $\mathrm{g} \mathrm{m}^{-2} \mathrm{~d}^{-1}$ in lettuce and basil, respectively (Figure 2). Similarly, it was also estimated that rocket and chicory could yield up to 1,500 and $1,100 \mathrm{~g} \mathrm{~m}^{-2} \mathrm{~d}^{-1}$ when grown in a 10-layer PFAL (Pennisi et al., 2019c) (Figure 2). Such values are in the range of 10- and up to 200-folds higher as compared respectively to the estimated SUE values of greenhouse and open-field cultivation for the same crops (Figure 2). Interestingly, when comparing land use in PFALs against traditional animal production systems, the SUE values were in the range of 1,000- to 55,000folds higher in the former (Figure 2), overall confirming the elevate potentialities for PFAL adoption in locations with limited land access and relevant food needs (e.g., highly dense cities) (Kozai, 2013). Besides, a further element for consideration when targeting SUE in PFALs is also associated with the overall strategies for cultivation management (including, e.g., spacing, transplant strategies, cultivation protocols and level of automation) (Kozai, 2019). Furthermore, it should be noted that potential yield and SUE value in PFAL is today only available for small-sized crops (e.g., leafy vegetables), whereas there is a lack of figures on plants that have larger size and vertical architecture (e.g., fruit vegetables such as tomato). Although preliminary indications are available for instance on dwarf-tomato (micro-tom) adaptability to PFAL environments (Kato et al., 2010; Kozai, 2019), further research is needed to clarify the potential productivity of such crop in a commercial scale.

\section{Energy use efficiency (EUE)}

PFALs rely for radiation on sole-source artificial lighting and therefore the system requires substantial electricity supply. Moreover, energy consumption is not only limited to lighting (50-55\%), but also associated with climate control (30-35\%, being lower when heat dissipation from the lamps is reduced) and production facilities (10-15\%) (Yokoyama, 2019). Thus, electrical energy-use costs of PFAL can be relatively higher as compared with conventional agriculture 


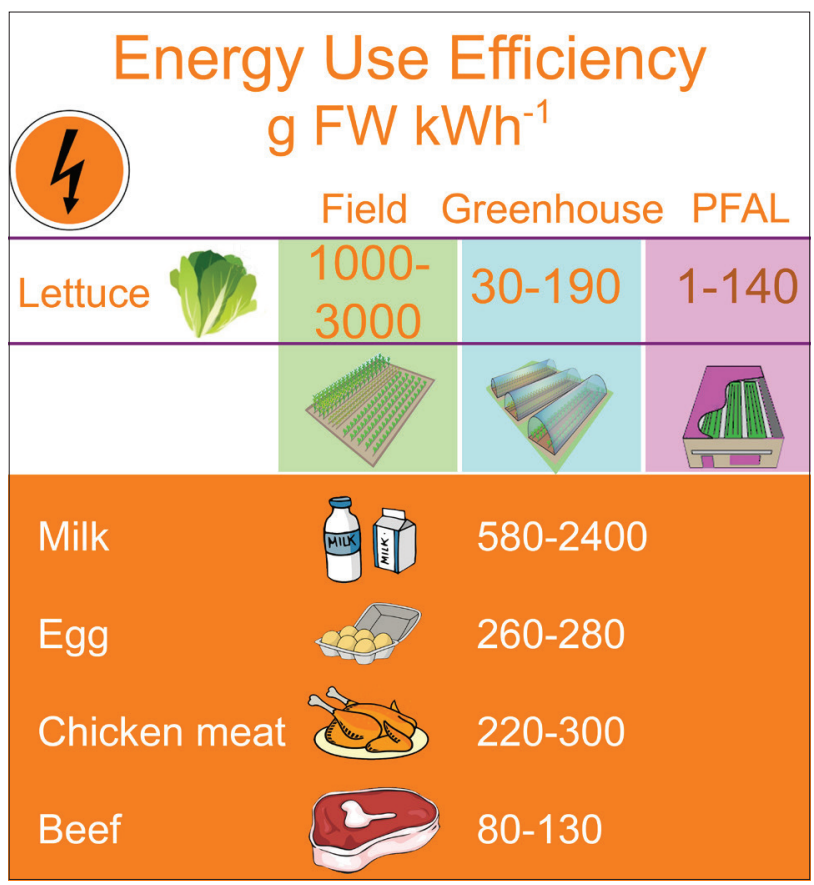

FigURE 3. Energy use efficiency (EUE) of selected food products in response to the cropping system. Values are based on literature on lettuce grown in open field (Barbosa et al., 2015; Martinez-Mate et al., 2018), greenhouse (Van Ginkel et al., 2017; Barbosa et al., 2015) and PFAL (Graamans et al., 2018; Kikuchi et al., 2018; Zhang et al., 2018; Kozai, 2019; Yokoyama, 2019). Values from comparison from animal-based products are obtained from De Vries and De Boer (2019).

(Barbosa et al., 2015; Shimizu et al., 2011) (Figure 3). With reference to lighting, EUE was shown to be dependent on lamp features, varying among commercial solutions (Zhang et al., 2018; Kong et al., 2019; Hernandez et al., 2020), and in response to the integration of zoom lens (Li et al., 2016) or the efficacy of the diodes (Kusuma et al., 2020) (Table 1). For instance, it was reported that red diodes produce more photons as compared to the blue ones (Blanken et al., 2013; Park and Runkle, 2018). However, with increasing junction temperature, blue diodes may enhance their efficacy compared to red diodes (Wang and Liang, 2007; Pennisi et al., 2019a). It emerges that not only the color properties of the diode should be considered, but also the working temperature of the lamp shall be taken into account when defining the energy requirements (Kusuma et al., 2020) (Table 1). Moreover, also the spectral composition was shown to alter plant growth and therefore EUE. Accordingly, when RB spectrum was supplied, it was also reported that RB ranging 2 to 4 would allow for optimized EUE in several crops (Kong et al., 2019; Pennisi et al., 2019a, b, c; Yan et al., 2019) (Table 1). Besides, since the electricity consumption is linked to the photosynthetic photon flux density (PPFD) emitted, the need for identifying species-specific optimal PPFD values was also evidenced (Yan et al., 2019). Among other possible strategies to reduce electricity needs in PFALs, the integration of photovoltaic (PV) panels on the outer surface of the building has been suggested (Uraisami, 2018), thanks to the recent reduction in costs associated with both PV technology and lithium batteries. However, the still limited energy efficiency at the panel (Dupraz et al., 2011), combined with energy losses

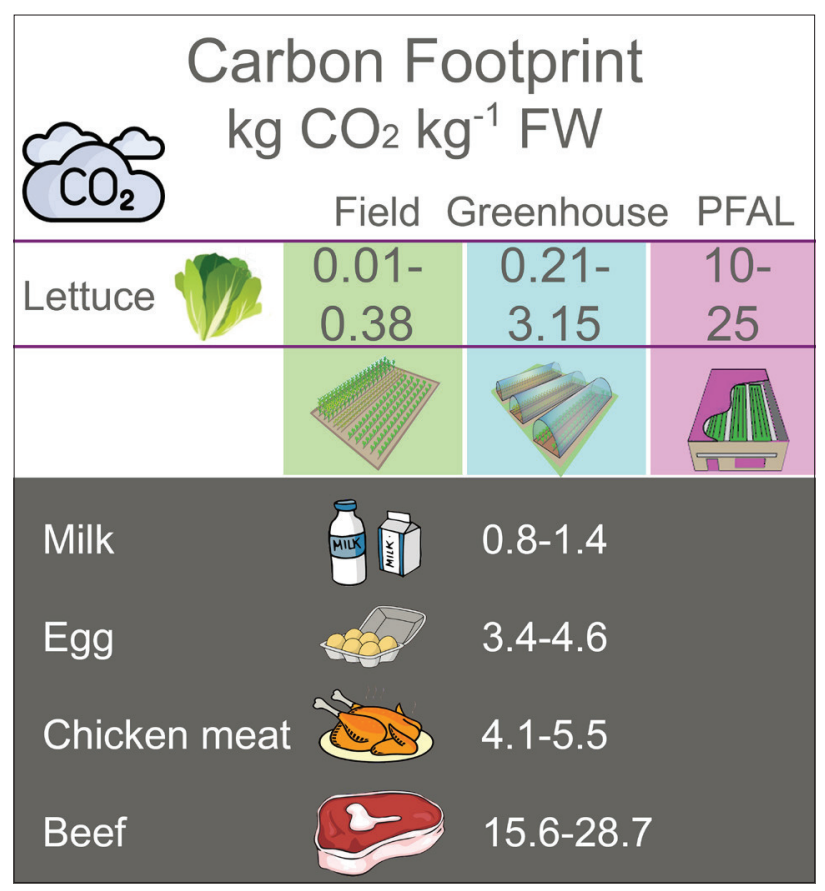

FIGURE 4. Carbon Environmental impact assessment of selected food products in response to the cropping system. Values are based on literature on lettuce grown in open field (Davis et al., 2011; Romero-Gamez et al., 2014; Bartzas et al., 2015; Foteinis and Chatzisymeon, 2016; Clune et al., 2017; Kikuchi et al., 2018; Martinez-Mate et al., 2018), greenhouse (Romero-Gamez et al., 2014; Bartzas et al., 2015; Clune et al., 2017) and PFAL (Kikuchi et al., 2018). Values from comparison from animal based products are obtained from De Vries and De Boer (2019) and Clune et al. (2017).

when electricity is transformed back into light (Kusuma et al., 2020) and the elevated light needs associated with multitier cultivation (Kozai and Niu, 2016), make it questionable whether PV panels may significantly contribute to the overall PFAL energy needs. Accordingly, when estimations on the PV requirements to cover PFAL needs were advanced (Uraisami, 2018), it was calculated that the PV surface should be 30 to 45 times higher than the actual land covered by a PFAL.

Literature on the potential EUE values in PFALs is to date mostly limited to lettuce crop, and often lacks conversion units to standardize values (e.g., between fresh and dry biomass, or between head and unit plant weight). Indeed, a rough estimation was hereby compiled (Figure 3), in order to stress the differences in EUE among production systems. Accordingly, EUE values were about 20-times lower in a PFAL as compared to open-field cultivation of lettuce, and generally lower also with respect to animal production systems, with the exception of beef production which featured similar values (Figure 3).

\section{Environmental assessment}

Despite the fact that PFALs are claimed to be resources-saving growing systems, in recent times only few studies have been published addressing their global environmental impact by applying the life cycle assessment (LCA) methodology. Romeo et al. (2018) evaluated and compared the environmental impact of the production of one $\mathrm{kg}$ of leafy greens in a PFAL (located in Lyon, France) against the production in a heated greenhouse or in open-field condition, by performing a cradle-to-gate analysis (from the cultivation phase to the 
transport to the retailers). The PFAL presented the best performance in the impact categories of marine eutrophication $(-87 \%$ and $-93 \%$ as compared to greenhouse and open-field cultivation, respectively) and agricultural land occupation (-95\% and $-75 \%$ as compared to greenhouse and open-field cultivation, respectively). Furthermore, performances of the PFAL in all impact categories (with the exception of water depletion) resulted higher as compared to the production in the greenhouse. The contribution of the different processes to the impact categories resulted different. Within the climate change impact category, electricity consumption contributed for $67 \%$ to the impact in the PFAL, while in open-field condition the production and use of fertilizers were the most impacting processes. The PFAL enabled a water consumption 7-times lower than greenhouse production, and 4-times lower than open-field cultivation (where also rainfall contributed to the overall water balance). However, in the PFAL, the constant water flow of the irrigation system was achieved by a greater use of electricity, whose impact resulted strictly correlated with the electricity source. Source such as nuclear energy, for instance, has a high requirement of cooling-water, which explains why the vertical hydroponic farm had a worse impact on water depletion, even if it had a smaller direct water consumption. Kikuchi et al. (2018) compared the environmental impact for the production of lettuce in a PFAL (located in Kashiwa, Japan) with conventional Japanese horticulture systems in open fields. The study reported that PFAL increased by 4 -folds and by 8 -folds the efficiency in the use of phosphorus and water, respectively, as compared to open field cultivation. This however was achieved at the cost of additional energy consumption, which was the largest contributor to GHG emissions. Compared with the results for the PFAL, conventional horticulture systems presented lower GHG emissions per unit mass of product (approximately 0.2 vs. $25 \mathrm{~kg} \mathrm{CO}_{2}$ eq. $\mathrm{kg}^{-1}$ lettuce, respectively for conventional farming and PFAL), even though such difference was not anymore evident when data were normalized for unit land surface used (much lower in the PFAL) and the seasonal and farm variability in conventional farming systems across Japan was taken into account (Figure 4) (Kikuchi et al., 2018). The study also highlighted that GHG emissions of PFAL can be reduced (up to $60 \%$ ) by the adoption of innovative and renewable energy technologies (e.g., the utilization of unused heat, a solid-oxide fuel cell, PV power, optimized electric devices such as heat pumps and lighting). Martin and Molin (2019) analyzed the environmental impacts of the annual production of plants in a vertical hydroponic farm (located in Stockholm, Sweden and producing potted basil plants), by performing a cradle-to-gate analysis and by comparing different technical solutions (e.g., plastic pots vs. paper pots, gardening soil vs. coir, or using different electricity supply combinations). The results highlighted that GHG emissions can be halved by substituting gardening soil to coir as growing media, while a reduction of $66 \%$ in the impact category of acidification can be achieved by substituting plastic pots with paper pots (Martin and Molin, 2019). In all scenarios, the impact of electricity, primarily associated with the lighting system, contributed from $20 \%$ to over $50 \%$ to the GHG emissions impact category, in line with previously published evidences (Romeo et al., 2018; Gomez and Izzo, 2018).

Based on the available literature, electricity requirement seems to be the most impacting factor in PFALs, therefore research must address resource-efficient solutions to reduce the impacts of electricity demand. Consequently, lighting management strategies (e.g., in terms of light quality, inten- sity and duration) may alter energy use efficiency in PFALs overall modifying their environmental performances. The environmental impact, the economic cost and the resulting eco-efficiency of the cultivation of leafy vegetables and herbs grown under different lighting solutions (e.g., different red and blue ratio within the light spectrum) were recently assessed (Pennisi et al., 2019c). It emerged that the improved eco-efficiency were associated with $\mathrm{RB}=3$ for lettuce, $\mathrm{RB}=2$ for basil, and $\mathrm{RB}=4$ for rocket and chicory cultivation. The same study also confirmed electricity consumption as the greatest contributor among all the impact categories assessed.

\section{Conclusion}

Production of fresh produce in PFALs may improve food system resilience to climate change and sustainable use of resources. However, for PFAL to actually be viable, a comprehensive vision that integrates most recent advances in lighting, hydroponics and climate control systems is required. While both water and land surface use efficiencies are improved in PFALs compared to conventional agriculture, energy requirements are elevated and result in large associated economic costs and environmental impacts. Despite advances that were made possible by LED technology, there is a great need for profiling optimal spectral and light management strategies in a wider range of crops beyond leafy greens. It is also crucial that integration of hydroponics and climate control units takes place, both building on the state-of-the-art of greenhouse technology, and specifically designing solutions adapted to multitier cultivation in a PFAL. Finally, future research should also further focus on existing PFALs in order to quantify resource use efficiency and environmental impacts on a commercial scale.

\section{Acknowledgments}

The research leading to this publication has received funding from the European Union's Horizon 2020 research and innovation programme under grant agreement No. 862663. The publication reflects the authors' views. The Research Executive Agency (REA) is not liable for any use that may be made of the information contained therein.

\section{References}

Alexandratos, N., and Bruinsma, J. (2012). World agriculture towards 2030/2050: the 2012 revision. ESA Working Paper N.12-03, Food and Agriculture Organisation of the United Nations (FAO).

Al-Kodmany, K. (2018). The vertical farm: A review of developments and implications for the vertical city. Buildings $8(2), 24$. https://doi. org/10.3390/buildings8020024.

AlShrouf, A. (2017). Hydroponics, aeroponic and aquaponic as compared with conventional farming. Am. Sci. Res. J. Eng. Technol. Sci. 27(1), 247-255.

Atzori, G., Nissim, W.G., Caparrotta, S., Santantoni, F., and Masi, E. (2019). Seawater and water footprint in different cropping systems: A chicory (Cichorium intybus L.) case study. Agr. Water Manag. 211, 172-177. https://doi.org/10.1016/j.agwat.2018.09.040.

Avgoustaki, D.D., and Xydis, G. (2020). Indoor vertical farming in the urban nexus context: business growth and resource savings. Sustainability 12(5), 1965. https://doi.org/10.3390/su12051965.

Azad, M.O.K., Kjaer, K.H., Adnan, M., Naznin, M.T., Lim, J.D., Sung, I.J., Park, C.H., and Lim, Y.S. (2020). The evaluation of growth performance, photosynthetic capacity, and primary and secondary metabolite content of leaf lettuce grown under limited irradiation of Blue and Red LED light in an urban plant factory. Agriculture 10(2), 28. https://doi.org/10.3390/agriculture10020028. 
Bantis, F., Smirnakou, S., Ouzounis, T., Koukounaras, A., Ntagkas, N., and Radoglou, K. (2018). Current status and recent achievements in the field of horticulture with the use of light-emitting diodes (LEDs). Sci. Hortic. 235, 437-451. https://doi.org/10.1016/j. scienta.2018.02.058.

Barbosa, G., Gadelha, F., Kublik, N., Proctor, A., Reichelm, L., Weissinger, E., Wohelleb, G.M., and Halden, R. (2015). Comparison of land, water, and energy requirements of lettuce grown using hydroponic vs. conventional agricultural methods. Int. J. Environ. Res. Public Health 12(6), 6879-6891. https://dx.doi. org/10.3390\%2Fijerph120606879.

Bartzas, G., Zaharaki, D., and Kostas, K. (2015). Life cycle assessment of open field and greenhouse cultivation of lettuce and barley. Inf. Process. Agric. 2(3), 191-207. https://doi.org/10.1016/j. inpa.2015.10.001.

Benis, K., and Ferrao, P. (2018). Commercial farming within the urban built environment. Taking stock of an evolving field in northern countries. Glob. Food Secur. Agric. Policy Econ. Environ. 17, 30-37. https://doi.org/10.1016/j.gfs.2018.03.005.

Blanken, W., Cuaresma, M., Wijffels, R.H., and Janssen, M. (2013). Cultivation of microalgae on artificial light comes at a cost. Algal Res. 2(4), 333-340. https://doi.org/10.1016/j.algal.2013.09.004.

Bortolini, L., and Tolomio, M. (2019). Influence of irrigation frequency on radicchio (Cichorium intybus L.) yield. Water 11(12), 2473. https://doi.org/10.3390/w11122473.

Bortolini, L., Nicoletto, C., Sambo, P., and Evans, M.R. (2016). Radicchio cultivation under different sprinkler irrigation systems. Contemp. Engin. Sci. 9, 345-355. http://dx.doi.org/10.12988/ ces.2016.613

Bugbee, B. (2017). Economics of LED lighting. In Light Emitting Diodes for Agriculture, S. Dutta Gupta, ed. (Singapore: Springer), p. 81-99. https://doi.org/10.1007/978-981-10-5807-3_5.

Calone, R., Pennisi, G., Morgenstern, R., Sanyé-Mengual, E., Lorleberg, W., Dapprich, P., Winkler, P., Orsini, F., and Gianquinto, G. (2019). Improving water management in European catfish recirculating aquaculture systems through catfish-lettuce aquaponics. Sci Total. Environm. 687, 759-767. https://doi.org/10.1016/j. scitotenv.2019.06.167.

Cantore, V., Pace, B., Calabrese, N., Boari, F., and Schiattone, M.I. (2012). Effects of non-woven fabric and fertilizer on air and soil temperature, leaf gas exchange, yield and quality of wild rocket grown in organic farming. Acta Hortic. 1005, 479-486. https://doi. org/10.17660/ActaHortic.2013.1005.58.

Cerrudo, I., Keller, M.M., Cargnel, M.D., Demkura, P.V., de Wit, M. Patitucci, M.S., Pierik, R., Pieterse, C.M.J., and Ballaré, C.L. (2013). Low red/far-red ratios reduce Arabidopsis resistance to Botrytis cinerea and jasmonate responses via a COI1-JAZ10-dependent, salicylic acid-independent mechanism. Plant Physiol. 158, 20422052. https://doi.org/10.1111/tpj.12203.

Chen, B., Han, M.Y., Peng, K., Zhou, S.L., Shao, L., Wu, X.F., Wei, W.D., Liu, S.Y., Li, Z., Li, J.S., and Chen, G.Q. (2018). Global land-water nexus: agricultural land and freshwater use embodied in worldwide supply chains. Sci. Total. Environm. 613, 931-943. https://doi. org/10.1016/j.scitotenv.2017.09.138.

Chen, X.L., Wang, L.C., Li, T., Yang, Q.C., and Guo, W.Z. (2019). Sugar accumulation and growth of lettuce exposed to different lighting modes of red and blue LED light. Sci. Rep. 9(1), 1-10. https://doi. org/10.1038/s41598-019-43498-8.

Cho, W.J., Kim, H.J., Jung, D.H., Kang, C.I., Choi, G.L., and Son, J.E. (2017). An embedded system for automated hydroponic nutrient solution management. Trans. ASABE 60, 1083-1096. https://doi. org/10.13031/trans.12163.
Clune, S., Crossin, E., and Verghese, K. (2017). Systematic review of greenhouse gas emissions for different fresh food categories. J. Clean. Prod. 140, 766-783. https://doi.org/10.1016/j.jclepro.2016.04.082.

Cordell, D., Drangert, J.O., and White, S. (2009). The story of phosphorus: global food security and food for thought. Global Environm. Change 19(2), 292-305. https://doi.org/10.1016/j. gloenvcha.2008.10.009.

Cree, Inc. (2017). Cree, Inc. Product Family Data Sheet Cree (Durham, NC, USA).

D’Imperio, M., Montesano, F.F., Renna, M., Leoni, B., Buttaro, D. Parente, A., and Serio, F. (2018). NaCl stress enhances silicon tissue enrichment of hydroponic "baby leaf" chicory under biofortification process. Sci. Hortic. 235, 258-263. https://doi.org/10.1016/j. scienta.2018.03.001.

Dalsgaard, J., Lund, I., Thorarinsdottir, R., Drengstig, A., Arvonen, K., and Pedersen, P.B. (2013). Farming different species in RAS in Nordic countries: current status and future perspectives. Aquac. Eng. 53, 2-13. https://doi.org/10.1016/j.aquaeng.2012.11.008.

Davis, J., Wallman, M., Sund, V., Emanuelsson, A., Cederberg, C., and Sonesson, U. (2011). Emissions of greenhouse gases from production of horticultural products: analysis of 17 products cultivated in Sweden. SIK Institutet för Livsmedel och Bioteknik.

De Vries, M., and De Boer, I.J.M. (2010). Comparing environmental impacts for livestock products: A review of life cycle assessments. Livest. Sci. 128, 1-11. https://doi.org/10.1016/j.livsci.2009.11.007.

Demirel, K., Camoglu, G., Genc, L., and Kizil, U. (2014). The variation of plant stress indicators and some traits under different irrigation and nitrogen levels in the rocket. Fresen. Environ. Bull. 23(5), 12381248.

Despommier, D. (2009). The rise of vertical farms. Sci. Am. 301(5), 80-87. https://doi.org/10.1038/scientificamerican1109-80.

Dupraz, C., Marrou, H., Talbot, G., Dufour, L., Nogier, A., and Ferard, Y. (2011). Combining solar photovoltaic panels and food crops for optimising land use: towards new agrivoltaic schemes. Renew. Energ. 36(10), 2725-2732. https://doi.org/10.1016/j.renene.2011.03.005.

Ekren, S., Sönmez, Ç., Özçakal, E., Kurttaș, Y.S.K., Bayram, E., and Gürgülü, H. (2012). The effect of different irrigation water levels on yield and quality characteristics of purple basil (Ocimum basilicum L.). Agric. Water Manag. 109, 155-161. https://doi.org/10.1016/j. agwat.2012.03.004.

Endo, M. (2019). Aquaponics in plant factory. In Plant Factory Using Artificial Light: Adapting to Environmental Disruption and Clues to Agricultural Innovation, M. Anpo, H. Fukuda, and T. Wada, eds. (Amsterdam, The Netherlands: Elsevier), p. 339-352. https://doi. org/10.1016/B978-0-12-813973-8.00032-4.

Folta, K.M., and Maruhnich, S.A. (2007). Green light: A signal to slow down or stop. J. Exp. Bot. 58(12), 3099-3111. https://doi. org/10.1093/jxb/erm130.

Fontana, E., and Nicola, S. (2009). Traditional and soilless culture systems to produce corn salad (Valerianella olitoria L.) and rocket (Eruca sativa Mill.) with low nitrate content. J. Food Agric. Environ. $7(2), 405-410$.

Foteinis, S., and Chatzisymeon, E. (2016). Life cycle assessment of organic versus conventional agriculture. A case study of lettuce cultivation in Greece. J. Clean. Prod. 112, 2462-2471. https://doi. org/10.1016/j.jclepro.2015.09.075.

Fukuda, N. (2019). Plant growth and physiological responses to light conditions. In Plant Factory Using Artificial Light: Adapting to Environmental Disruption and Clues to Agricultural Innovation, M. Anpo, H. Fukuda, and T. Wada, eds. (Amsterdam, The Netherlands: Elsevier), p. 71-77. https://doi.org/10.1016/B978-0-12-8139738.00008-7. 
Gianquinto, G., and Pimpini, F. (1989). The influence of temperature on growth, bolting and yield of chicory cv. Rosso di Chioggia (Cichorium intybus L.). J. Hortic. Sci. 64(6), 687-695. https://doi.or g/10.1080/14620316.1989.11516010.

Goddek, S., Delaide, B., Mankasingh, U., Ragnarsdottir, K.V., Jijakli, H., and Thorarinsdottir, R. (2015). Challenges of sustainable and commercial aquaponics. Sustainability 7(4), 4199-4224. https:// doi.org/10.3390/su7044199.

Gómez, C., and Izzo, L.G. (2018). Increasing efficiency of crop production with LEDs. AIMS Agric. Food 3(2), 135-153. http:// dx.doi.org/10.3934/agrfood.2018.2.135.

Gómez, C., Currey, C.J., Dickson, R.W., Kim, H.J., Hernández, R., Sabeh, N.C., Raudales, R.E., Brumfield, R.G., Laury-Shaw, A., Wilke, A.K., Lopez, R.G., and Burnett, S.E. (2019). Controlled environment food production for urban agriculture. HortScience 54(9), 1448-1458. https://doi.org/10.21273/HORTSCI14073-19.

Graamans, L., Baeza, E., Van den Dobbelsteen, A., Tsafaras, I., and Stanghellini, C. (2018). Plant factories versus greenhouses: comparison of resource use efficiency. Agric. Sys. 160, 31-43. https://doi.org/10.1016/j.agsy.2017.11.003.

Graamans, L., Tenpierik, M., Van den Dobbelsteen, A., and Stanghellini, C. (2020). Plant factories: Reducing energy demand at high internal heat loads through façade design. Appl. Energ. 262, 114544. https:// doi.org/10.1016/j.apenergy.2020.114544.

Guo, J., and Wang, M.H. (2010). Ultraviolet A-specific induction of anthocyanin biosynthesis and PAL expression in tomato (Solanum lycopersicum L.). Plant Growth Reg. 62(1), 1-8. https://doi. org/10.1007/s10725-010-9472-y.

Hernandez, E., Timmons, M.B., and Mattson, N.S. (2020). Quality, yield, and biomass efficacy of several hydroponic lettuce (Lactuca sativa L.) cultivars in response to high pressure sodium lights or light emitting diodes for greenhouse supplemental lighting. Horticulturae 6(1), 7. https://doi.org/10.3390/horticulturae6010007.

Hogewoning, S.W., Trouwborst, G., Maljaars, H., Poorter, H., Van Ieperen, W., and Harbinson, J. (2010). Blue light dose-responses of leaf photosynthesis, morphology, and chemical composition of Cucumis sativus grown under different combinations of red and blue light. J. Exp. Bot. 61(11), 3107-3117. https://doi.org/10.1093/jxb/ erq132.

Ioslovich, I., and Gutman, P.O. (2000). Optimal control of crop spacing in a plant factory. Automatica 36(11), 1665-1668. https:// doi.org/10.1016/S0005-1098(00)00086-8.

IPCC (2014). Mitigation of climate change. Working Group III contribution to the fifth assessment report of the Intergovernmental Panel on Climate Change (New York, US: Cambridge University Press).

Janssen, R.J.P., Krijn, M.P.C.M., Van den Bergh, T., Van Elmpt, R.F.M., Nicole, C.C., and Van Slooten, U. (2019). Optimizing plant factory performance for local requirements. In Plant Factory Using Artificial Light: Adapting to Environmental Disruption and Clues to Agricultural Innovation, M. Anpo, H. Fukuda, and T. Wada, eds (Amsterdam, The Netherlands: Elsevier), p. 281-293. https://doi. org/10.1016/B978-0-12-813973-8.00025-7.

Ji, Y., Ouzounis, T., Courbier, S., Kaiser, E., Nguyen, P.T., Schouten, H.J., Visser, R.G.F., Pierik, R., Marcelis, L.F.M., and Heuvelink, E. (2019). Far-red radiation increases dry mass partitioning to fruits but reduces Botrytis cinerea resistance in tomato. Env. Exp. Bot. 168, 103889. https://doi.org/10.1016/j.envexpbot.2019.103889.

Jung, D.H., Kim, H.J., Cho, W.J., Park, S.H., and Yang, S.H. (2019) Validation testing of an ion-specific sensing and control system for precision hydroponic macronutrient management. Comput. Electron. Agric. 156, 660-668. https://doi.org/10.1016/j. compag.2018.12.025.
Kalaitzoglou, P., Van Ieperen, W., Harbinson, J., Van der Meer, M., Martinakos, S., Weerheim, K., Nicole, C., and Marcelis, L. (2019). Effects of continuous or end-of-day far-red light on tomato plant growth, morphology, light absorption and fruit production. Front. Plant. Sci. 10, 322. https://doi.org/10.3389/fpls.2019.00322.

Kalamartzis, I., Dordas, C., Georgiou, P., and Menexes, G. (2020). The use of appropriate cultivar of basil (Ocimum basilicum) can increase water use efficiency under water stress. Agronomy 10(1), 70. https://doi.org/10.3390/agronomy10010070.

Kalantari, F., Tahir, O.M., Joni, R.A., and Fatemi, E. (2018). Opportunities and challenges in sustainability of vertical farming: A review. J. Landscape Ecol. 11(1), 35-60. https://doi.org/10.1515/ jlecol-2017-0016.

Kato, K., Yoshida, R., Kikuzaki, A., Hirai, T., Kuroda, H., Hiwasa-Tanase, K., Ezura, H., and Mizoguchi, T. (2010). Molecular breeding of tomato lines for mass production of miraculin in a plant factory. J. Agric. Food Chem. 58(17), 9505-9510. https://doi.org/10.1021/jf101874b.

Kikuchi, Y., Kanematsu, Y., Yoshikawa, N., Okubo, T., and Takagaki, M. (2018). Environmental and resource use analysis of plant factories with energy technology options: A case study in Japan. J. Cleaner. Prod. 186, 703-717. https://doi.org/10.1016/j.jclepro.2018.03.110.

Kong, Y., Nemali, A., Mitchell, C., and Nemali, K. (2019). Spectral quality of light can affect energy consumption and energy-use efficiency of electrical lighting in indoor lettuce farming. HortScience 54(5), 865-872. https://doi.org/10.21273/HORTSCI13834-18.

Kozai, T. (2013). Resource use efficiency of closed plant production system with artificial light: Concept, estimation and application to plant factory. Proc. Japan Acad. 89447461. https://doi.org/10.2183/ pjab.89.447.

Kozai, T. (2019). Towards sustainable plant factories with artificial lighting (PFALs) for achieving SDGs. Int. J. Agric. Biol. Eng. 12(5), 28-37. https://doi.org/10.25165/j.ijabe.20191205.5177.

Kozai, T., and Niu, G. (2016). Plant factory as a resource-efficient closed plant production system. In Plant Factory: An Indoor Vertical Farming System for Efficient Quality Food Production, T. Kozai, G. Niu, and M. Takagaki, eds. (Cambridge, US: Academic Press), p. 6990. https://doi.org/10.1016/B978-0-12-801775-3.00004-4.

Kozai, T., Sakaguchi, S., Akiyama, T., Yamada, K., and Ohshima, K. (2016) Design and management of PFAL. In Plant Factory: An Indoor Vertical Farming System for Efficient Quality Food Production, T. Kozai, G. Niu, and M. Takagaki, eds. (Cambridge, US: Academic Press), p. 295-312. https://doi.org/10.1016/B978-0-12-801775-3.00022-6.

Kozai, T., Amagai, Y., and Hayashi, E. (2019). Towards sustainable plant factories with artificial lighting (PFALs): from greenhouses to vertical farms (Ch. 6). In Achieving Sustainable Greenhouse Cultivation, L. Marcelis, and E. Heuvelink, eds. (Cambridge, UK: Burleigh Dodds Science Publishing), p. 177-204. http://dx.doi. org/10.19103/AS.2019.0052.06.

Kuronuma, T., Watanabe, Y., Ando, M., and Watanabe, H. (2018). Tipburn severity and calcium distribution in Lisianthus (Eustoma grandiflorum (Raf.) Shinn.) cultivars under different relative air humidity conditions. Agronomy 8(10), 218. https://doi. org/10.3390/agronomy8100218.

Kusuma, P., Pattison, P.M., and Bugbee, B. (2020). From physics to fixtures to food: current and potential LED efficacy. Hortic. Res. 7(1), 1-9. https://doi.org/10.1038/s41438-020-0283-7.

Lakhiar, I.A., Gao, J., Syed, T.N., Chandio, F.A., and Buttar, N.A. (2018). Modern plant cultivation technologies in agriculture under controlled environment: A review on aeroponics. J. Plant Interact. 13(1), 338-352. https://doi.org/10.1080/17429145.2018.1472308.

Lal, R. (2018). Saving global land resources by enhancing ecoefficiency of agroecosystems. J. Soil Water Conserv. 73(4), 100A-106A. https://doi.org/10.2489/jswc.73.4.100A. 
Lambin, E.F., and Meyfroidt, P. (2011). Global land use change, economic globalization, and the looming land scarcity. Proc. Natl. Acad. Sci. USA 108, 3465-3472. https://doi.org/10.1073/ pnas.1100480108.

Li, K., Yang, Q.C., Tong, Y.X., and Cheng, R. (2014). Using movable lightemitting diodes for electricity savings in a plant factory growing lettuce. HortTechnology 24(5), 546-553. https://doi.org/10.21273/ HORTTECH.24.5.546.

Li, K., Li, Z., and Yang, Q. (2016). Improving light distribution by zoom lens for electricity savings in a plant factory with lightemitting diodes. Front. Plant Sci. 7, 92. https://doi.org/10.3389/ fpls.2016.00092.

Li, Q., and Kubota, C. (2009). Effects of supplemental light quality on growth and phytochemicals of baby leaf lettuce. Env. Exp. Bot. 67(1), 59-64. https://doi.org/10.1016/j.envexpbot.2009.06.011.

Li, X., Zhou, Y., Eom, J., Yu, S., and Asrar, G.R. (2019). Projecting global urban area growth through 2100 based on historical time series data and future shared socioeconomic pathways. Earth's Future 7(4), 351-362. https://doi.org/10.1029/2019EF001152.

Liu, W., and Yang, Q. (2012). Effects of supplemental UV-a and UV-c irradiation on growth, photosynthetic pigments and nutritional quality of pea seedlings. Acta Hortic. 956, 657-663. https://doi. org/10.17660/ActaHortic.2012.956.79.

Liu, W., Chen, D.K., and Liu, Z.X. (2004). High efficiency column culture system in China. Acta Hortic. 691, 495-500. https://doi. org/10.17660/ActaHortic.2005.691.58.

Mahmoud, A.W.M., and Taha, S.S. (2018). Main sulphur content in essential oil of Eruca sativa as affected by nano iron and nano zinc mixed with organic manure. Agriculture (Pol'nohospodárstvo) 64(2), 65-79. https://doi.org/10.2478/agri-2018-0007.

Maldonado, A.I.L., Reyes, J.M.M., Breceda, H.F., Fuentes, H.R., Contreras, J.A.V., and Maldonado, U.L. (2019). Automation and robotics used in hydroponic system. In Urban Horticulture - Necessity of the Future, S.S. Solankey, S. Akhtar, A.I.L. Maldonado, H. Rodriguez-Fuentes, J.A.V. Contreras, and J.M.M. Reyes, eds. (London, UK: IntechOpen). https://doi.org/10.5772/intechopen.90438.

Maraseni, T.N., Mushtaq, S., and Reardon-Smith, K. (2012). Integrated analysis for a carbon-and water-constrained future: An assessment of drip irrigation in a lettuce production system in eastern Australia. J. Environ. Manag. 111, 220-226. https://doi.org/10.1016/j. jenvman.2012.07.020.

Martin, M., and Molin, E. (2019). Environmental assessment of an urban vertical hydroponic farming system in Sweden. Sustainability 11(15), 4124. https://doi.org/10.3390/su11154124.

Martinez-Mate, M.A., Martin-Gorriz, B., Martínez-Alvarez, V., SotoGarcía, M., and Maestre-Valero, J.F. (2018). Hydroponic system and desalinated seawater as an alternative farm-productive proposal in water scarcity areas: energy and greenhouse gas emissions analysis of lettuce production in southeast Spain. J. Clean. Prod. 172, 12981310. https://doi.org/10.1016/j.jclepro.2017.10.275.

Mekonnen, M.M., and Hoekstra, A.Y. (2012). A global assessment of the water footprint of farm animal products. Ecosystems 15(3), 401415. https://doi.org/10.1007/s10021-011-9517-8.

Mekonnen, M.M., Neale, C.M., Ray, C., Erickson, G.E., and Hoekstra, A.Y. (2019). Water productivity in meat and milk production in the US from 1960 to 2016. Environ. Int. 132, 105084. https://doi. org/10.1016/j.envint.2019.105084.

Miceli, A., Moncada, A., Sabatino, L., and Vetrano, F. (2019). Effect of gibberellic acid on growth, yield, and quality of leaf lettuce and rocket grown in a floating system. Agronomy 9(7), 382. https://doi. org/10.3390/agronomy9070382.
Montesano, F.F., Van Iersel, M.W., Boari, F., Cantore, V., D’Amato, G., and Parente, A. (2018). Sensor-based irrigation management of soilless basil using a new smart irrigation system: Effects of set-point on plant physiological responses and crop performance. Agric. Water Manag. 203, 20-29. https://doi.org/10.1016/j.agwat.2018.02.019.

Moosavi, S.G.R. (2012). Effects of irrigation and nitrogen (N) fertilization levels on yield, morphological traits and water use efficiency of chicory (Cichorium intybus L.). J. Med. Plants Res. 6 4647-4652. https://doi.org/10.5897/JMPR11. 1724.

Naznin, M.T., Lefsrud, M., Gravel, V., and Hao, X. (2016). Using different ratios of red and blue LEDs to improve the growth of strawberry plants. Acta Hortic. 1134, 125-130. https://doi.org/10.17660/ ActaHortic.2016.1134.17.

Nelson, J.A., and Bugbee, B. (2014). Economic analysis of greenhouse lighting: light emitting diodes vs. high intensity discharge fixtures. PLoS ONE 9(6), e99010. https://doi.org/10.1371/journal. pone.0099010.

Nguyen, T.L.T., Hermansen, J.E., and Mogensen, L. (2010). Environmental consequences of different beef production systems in the EU. J. Clean. Prod. 18(8), 756-766. https://doi.org/10.1016/j. jclepro.2009.12.023.

Nicola, S., Hoeberechts, J., Fontana, E., and Saglietti, D. (2003). Cultural technique influences on post-harvest quality of rocket (Eruca sativa Mill.). Acta Hortic. 604, 685-690. https://doi.org/10.17660/ ActaHortic.2003.604.85.

Nicola, S., Hoeberechts, J., and Fontana, E. (2005). Comparison between traditional and soilless culture systems to produce rocket (Eruca sativa) with low nitrate content. Acta Hortic. 697, 549-555. https://doi.org/10.17660/ActaHortic.2005.697.72.

Nicole, C.C.S., Charalambous, F., Martinakos, S., Van de Voort, S., Li, Z., Verhoog, M., and Krijn, M.P.C.M. (2016). Lettuce growth and quality optimization in a plant factory. Acta Hortic. 1134, 231-238. https:// doi.org/10.17660/ActaHortic.2016.1134.31

Ohyama, K., Kozai, T., and Yoshinaga, K. (2000). Electric energy, water and carbon dioxide utilization efficiencies of a closed-type transplant production system. In Transplant Production in the $21^{\text {st }}$ Century, C. Kubota, and C. Chun, eds. (Berlin, Germany: Springer), p. 28-32. https://doi.org/10.1007/978-94-015-9371-7_3.

Orsini, F., Gasperi, D., Marchetti, L., Piovene, C., Draghetti, S., Ramazzotti, S., Bazzocchi, G., and Gianquinto, G. (2014). Exploring the production capacity of rooftop gardens (RTGs) in urban agriculture: the potential impact on food and nutrition security, biodiversity and other ecosystem services in the city of Bologna. Food Sec. 6(6), 781792. https://doi.org/10.1007/s12571-014-0389-6.

Ouzounis, T., Rosenqvist, E., and Ottosen, C.O. (2015). Spectral effects of artificial light on plant physiology and secondary metabolism: A review. HortScience 50(8), 1128-1135. https://doi.org/10.21273/ HORTSCI.50.8.1128.

Palada, M.C., Crossman, S., and Kowalski, J.A. (1995). Organic and synthetic mulches affect yield of basil under drip irrigation Caribb. Food Crops Soc. 31, 133-142. https://doi.org/10.22004/ ag.econ.257063.

Palm, H.W., Knaus, U., Appelbaum, S., Goddek, S., Strauch, S.M., Vermeulen, T., Jijakli, M.H., and Kotzen, B. (2018). Towards commercial aquaponics: A review of systems, designs, scales and nomenclature. Aquacult. Int. 26(3), 813-842. https://doi. org/10.1007/s10499-018-0249-z.

Park, K.S., Kim, S.K., Lee, S.G., Lee, H.J., and Kwon, J.K. (2018). Application of plasma lighting for growth and flowering of tomato plants. Horticult., Environm. Biotechnol. 59(6), 827-833. https:// doi.org/10.1007/s13580-018-0052-9. 
Park, Y., and Runkle, E.S. (2017). Far-red radiation promotes growth of seedlings by increasing leaf expansion and wholeplant net assimilation. Environ. Exp. Bot. 136, 41-49. https://doi. org/10.1016/j.envexpbot.2016.12.013.

Park, Y., and Runkle, E.S. (2018). Spectral effects of light-emitting diodes on plant growth, visual color quality, and photosynthetic photon efficacy: White versus blue plus red radiation. PloS ONE 13(8), e0202386. https://doi.org/10.1371/journal.pone.0202386.

Pastor, A.V., Palazzo, A., Havlik, P., Biemans, H., Wada, Y., Obersteiner, M., Kabat, P., and Ludwig, F. (2019). The global nexus of food-tradewater sustaining environmental flows by 2050. Nat. Sustain. 2(6), 499. https://doi.org/10.1038/s41893-019-0287-1.

Patel, J.R., Patel, J.B., Upadhyay, P.N., and Usadadia, V.P. (2000). The effect of various agronomic practices on the yield of chicory (Cichorium intybus). J. Agric. Sci. 135(3), 271-278. https://doi. org/10.1017/S0021859699008229.

Patle, G.T., Kumar, M., and Khanna, M. (2019). Climate-smart water technologies for sustainable agriculture: A review. J. Water. Clim. Change (in press). https://doi.org/10.2166/wcc.2019.257.

Pennisi, G., Blasioli, S., Cellini, A., Maia, L., Crepaldi, A., Braschi, I., Spinelli, F., Nicola, S., Fernandez, J.A., Stanghellini, C., Marcelis, L.F.M., and Orsini, F. (2019a). Unravelling the role of red:blue LED lights on resource use efficiency and nutritional properties of indoor grown sweet basil. Front. Plant. Sci. 10, 305. https://doi.org/10.3389/ fpls.2019.00305.

Pennisi, G., Orsini, F., Blasioli, S., Cellini, A., Crepaldi, A., Braschi, I, Spinelli, F., Nicola, S., Fernandez, J.A., Stanghellini, C., Gianquinto, G., and Marcelis, L.F.M. (2019b). Resource use efficiency of indoor lettuce (Lactuca sativa L.) cultivation as affected by red:blue ratio provided by LED lighting. Nat. Sci. Rep. 9(1), 1-11. https://doi. org/10.1038/s41598-019-50783-z.

Pennisi, G., Sanyé-Mengual, E., Orsini, F., Crepaldi, A., Nicola, S., Ochoa, J., Fernandez, J.A., and Gianquinto, G. (2019c). Modelling environmental burdens of indoor-grown vegetables and herbs as affected by red and blue LED lighting. Sustainability 11(15), 4063. https://doi.org/10.3390/su11154063.

Philips Lumileds Lighting (2017). Philips Lumileds Lighting LUXEON Rebel Color Portfolio. Data-sheet DS68:20171106 (Amsterdam, The Netherlands: Philips Lumileds Lighting Co.).

Pimpini, F., and Gianquinto, G. (1987). The influence of climatic conditions and age of plant at transplanting on bolting and yield of chicory (Cichorium intybus L.) cv. Rosso di Chioggia grown for early production. Acta Hortic. 229, 379-386. https://doi.org/10.17660/ ActaHortic.1988.229.42.

Pison, G. (2019). The population of the world. Popul. Soc. 8, 1-8. https://doi.org/10.3917/popsoc.569.0001.

Qiao, J., and Zhang, Z. (2014). Fiber-guided sunlight cultivation system for three-dimensional greenhouse. In Light, Energy and the Environment, OSA Technical Digest (online), Optical Society of America, paper JW6A.35. https://doi.org/10.1364/E2.2014. JW6A.35.

Rabbi, B., Chen, Z.H., and Sethuvenkatraman, S. (2019). Protected cropping in warm climates: A review of humidity control and cooling methods. Energies 12(14), 2737. https://doi.org/10.3390/ en12142737.

Rakocy, J.E. (2012). Aquaponics: integrating fish and plant culture. Aquacult. Prod. Sys. 1, 344-386. https://doi. org/10.1002/9781118250105.ch14.

Richter, J.L., Tähkämö, L., and Dalhammar, C. (2019). Trade-offs with longer lifetimes? The case of LED lamps considering product development and energy contexts. J. Clean. Prod. 226, 195-209. https://doi.org/10.1016/j.jclepro.2019.03.331.
Rius-Ruiz, F.X., Andrade, F.J., Riu, J., and Rius, F.X. (2014). Computeroperated analytical platform for the determination of nutrients in hydroponic systems. Food Chem. 147, 92-97. https://doi. org/10.1016/j.foodchem.2013.09.114.

Romeo, D., Vea, E.B., and Thomsen, M. (2018). Environmental impacts of urban hydroponics in Europe: A case study in Lyon. Procedia CIRP 69, 540-545. https://doi.org/10.1016/j.procir.2017.11.048.

Romero-Gámez, M., Audsley, E., and Suárez-Rey, E.M. (2014). Life cycle assessment of cultivating lettuce and escarole in Spain. J. Clean. Prod. 73, 193-203. https://doi.org/10.1016/j.jclepro.2013.10.053.

Saengtharatip, S., Goto, N., Kozai, T., and Yamori, W. (2020). Green light penetrates inside crisp head lettuce leading to chlorophyll and ascorbic acid content enhancement. Acta Hortic. 1273, 261-270. https://doi.org/10.17660/ActaHortic.2020.1273.35.

Saha, S., Monroe, A., and Day, M.R. (2016). Growth, yield, plant quality and nutrition of basil (Ocimum basilicum L.) under soilless agricultural systems. Ann. Agric. Sci. 61(2), 181-186. https://doi. org/10.1016/j.aoas.2016.10.001.

Sanyé-Mengual, E., Cerón-Palma, I., Oliver-Solà, J., Montero, J.I., and Rieradevall, J. (2015). Integrating horticulture into cities: A guide for assessing the implementation potential of rooftop greenhouses in industrial and logistics parks. J. Urban Technol. 22(1), 87-111. https://doi.org/10.1080/10630732.2014.942095.

Sardans, J., and Peñuelas, J. (2015). Potassium: A neglected nutrient in global change. Global Ecol. Biogeogr. 24(3), 261-275. https://doi. org/10.1111/geb.12259.

Savvas, D., Gianquinto, G., Tüzel, Y., and Gruda, N. (2013). Soilless culture. In Good Agricultural Practices Principles for Greenhouse Vegetable Production in the Mediterranean Region. FAO Paper, AGP series No. 217, p. 303-354.

Schiattone, M.I., Candido, V., Cantore, V., Montesano, F.F., and Boari, F. (2017). Water use and crop performance of two wild rocket genotypes under salinity conditions. Agric. Water Manag. 194, 214221. https://doi.org/10.1016/j.agwat.2017.09.009.

Shimizu, H., Saito, Y., Nakashima, H., Miyasaka, J., and Ohdoi, K. (2011). Light environment optimization for lettuce growth in plant factory. IFAC Proc. 44, 605-609. https://doi.org/10.3182/20110828-6IT-1002.02683.

Smith, H.L., McAusland, L., and Murchie, E.H. (2017). Don't ignore the green light: Exploring diverse roles in plant processes. J. Exp. Bot. 68(9), 2099-2110. https://doi.org/10.1093/jxb/erx098.

Son, J.E., Kim, H.J., and Ahn, T.I. (2020). Hydroponic systems. In Plant Factory: An Indoor Vertical Farming System for Efficient Quality Food Production, $2^{\text {nd }}$ edn., T. Kozai, G. Niu, and M. Takagaki, eds. (Cambridge, US: Academic Press), p. 273-283. https://doi. org/10.1016/B978-0-12-816691-8.00020-0.

Song, B.M., Han, B., and Lee, J.H. (2013). Optimum design domain of LED-based solid state lighting considering cost, energy consumption and reliability. Microelectron. Reliab. 53, 435-442. https://doi. org/10.1016/j.microrel.2012.10.010.

Song, S., Kusuma, P., Carvalho, S.D., Li, Y., and Folta, K.M. (2019). Manipulation of seedling traits with pulsed light in closed controlled environments. Environ. Exp. Bot. 166, 103803. https://doi. org/10.1016/j.envexpbot.2019.103803.

Stadler, M.M., Baganz, D., Vermeulen, T., and Keesman, K.J. (2015). Circular economy and economic viability of aquaponic systems: comparing urban, rural and peri-urban scenarios under Dutch conditions. Acta Hortic. 1176, 101-114. https://doi.org/10.17660/ ActaHortic.2017.1176.14.

Stutte, G.W. (2015). Commercial transition to LEDs: A pathway to high-value products. HortScience 50(9), 1297-1300. https://doi. org/10.21273/HORTSCI.50.9.1297. 
Terashima, I., Fujita, T., Inoue, T., Chow, W.S., and Oguchi, R. (2009). Green light drives leaf photosynthesis more efficiently than red light in strong white light: Revisiting the enigmatic question of why leaves are green. Plant. Cell. Physiol. 50(4), 684-697. https://doi. org/10.1093/pcp/pcp034.

Thomaier, S., Specht, K., Henckel, D., Dierich, A., Siebert, R., Freisinger, U., and Sawicka, M. (2015). Farming in and on urban buildings: Present practice and specific novelties of Zero-Acreage Farming (ZFarming). Renew Agric. Food Syst. 30(1), 43-54. https:// doi:10.1017/S1742170514000143.

Thorarinsdottir, R.I. (2015). Aquaponics Guidelines (Reykjavik, Iceland: Haskolaprent).

Touliatos, D., Dodd, I.C., and McAinsh, M. (2016). Vertical farming increases lettuce yield per unit area compared to conventional horizontal hydroponics. Food Energy Secur. 5(3), 184-191. https:// doi.org/10.1002/fes3.83.

Uraisami, K. (2018). Renewable energy makes plant factory "smart". In Smart Plant Factory, T. Kozai, ed. (Singapore: Springer), p. 119123. https://doi.org/10.1007/978-981-13-1065-2_7.

Van Ginkel, S.W., Igou, T., and Chen, Y.S. (2017). Energy, water and nutrient impacts of California-grown vegetables compared to controlled environmental agriculture systems in Atlanta, GA. Resour. Conserv. Recycl. 122, 319-325. https://doi.org/10.1016/j. resconrec.2017.03.003.

Wada, T. (2019). Theory and technology to control the nutrient solution of hydroponics. In Plant Factory Using Artificial Light: Adapting to Environmental Disruption and Clues to Agricultural Innovation, M. Anpo, H. Fukuda, and T. Wada, eds. (Amsterdam, The Netherlands: Elsevier), p. 5-14. https://doi.org/10.1016/B978-012-813973-8.00001-4

Wang, J., and Liang, B.W. (2007). Simulation of pn junction temperature of LED with finite element analysis. Semicond. PhotoOpt. $28(2), 228$.

Wang, J., Lu, W., Tong, Y., and Yang, Q. (2016). Leaf morphology, photosynthetic performance, chlorophyll fluorescence, stomatal development of lettuce (Lactuca sativa L.) exposed to different ratios of red light to blue light. Front. Plant. Sci. 7, 250. https://doi. org/10.3389/fpls.2016.00250.

Wu, B.S., Hitti, Y., MacPherson, S., Orsat, V., and Lefsrud, M.G. (2019). Comparison and perspective of conventional and LED lighting for photobiology and industry applications. Environm. Exp. Bot. 171, 103953. https://doi.org/10.1016/j.envexpbot.2019.103953.

Xu, Y. (2019). Nature and source of light for plant factory. In Plant Factory Using Artificial Light: Adapting to Environmental Disruption and Clues to Agricultural Innovation, M. Anpo, H. Fukuda, and T. Wada, eds. (Amsterdam, The Netherlands: Elsevier), p. 47-69. https://doi.org/10.1016/B978-0-12-813973-8.00002-6.

Yalçın, R.A., and Ertürk, H. (2020). Improving crop production in solar illuminated vertical farms using fluorescence coatings. Biosys. Eng. 193, 25-36. https://doi.org/10.1016/j.biosystemseng.2020.02.007.

Yan, Z., He, D., Niu, G., Zhou, Q., and Qu, Y. (2019). Growth, nutritional quality, and energy use efficiency of hydroponic lettuce as influenced by daily light integrals exposed to white versus white plus red lightemitting diodes. HortScience 54(10), 1737-1744. https://doi. org/10.21273/HORTSCI14236-19.

Yokoyama, R. (2019). Energy consumption and heat sources in plant factories. In Plant Factory Using Artificial Light: Adapting to Environmental Disruption and Clues to Agricultural Innovation, M. Anpo, H. Fukuda, and T. Wada, eds. (Amsterdam, The Netherlands: Elsevier), p. 177-184. https://doi.org/10.1016/B978-0-12-8139738.00016-6.
Zhang, X., He, D., Niu, G., Yan, Z., and Song, J. (2018). Effects of environment lighting on the growth, photosynthesis, and quality of hydroponic lettuce in a plant factory. Int. J. Agric. Biol. Eng. 11(2), 33-40. https://doi.org/10.25165/j.ijabe.20181102.3240.

Received: Apr. 16, 2020

Accepted: Jun. 15, 2020

Addresses of authors:

F. Orsini ${ }^{1}$, G. Pennisi ${ }^{1}$, F. Zulfiqar ${ }^{2}$ and G. Gianquinto ${ }^{1}$

${ }^{1}$ Research Centre on Urban Environment for Agriculture and Biodiversity, Agricultural Sciences Department, Alma Mater Studiorum - University of Bologna, Bologna, Italy

${ }^{2}$ Institute of Horticultural Sciences, Faculty of Agriculture, University of Agriculture Faisalabad, Pakistan 
International Workshop on Vertical Farming

13-15 October 2019

Wageningen, The Netherlands

Sponsored by
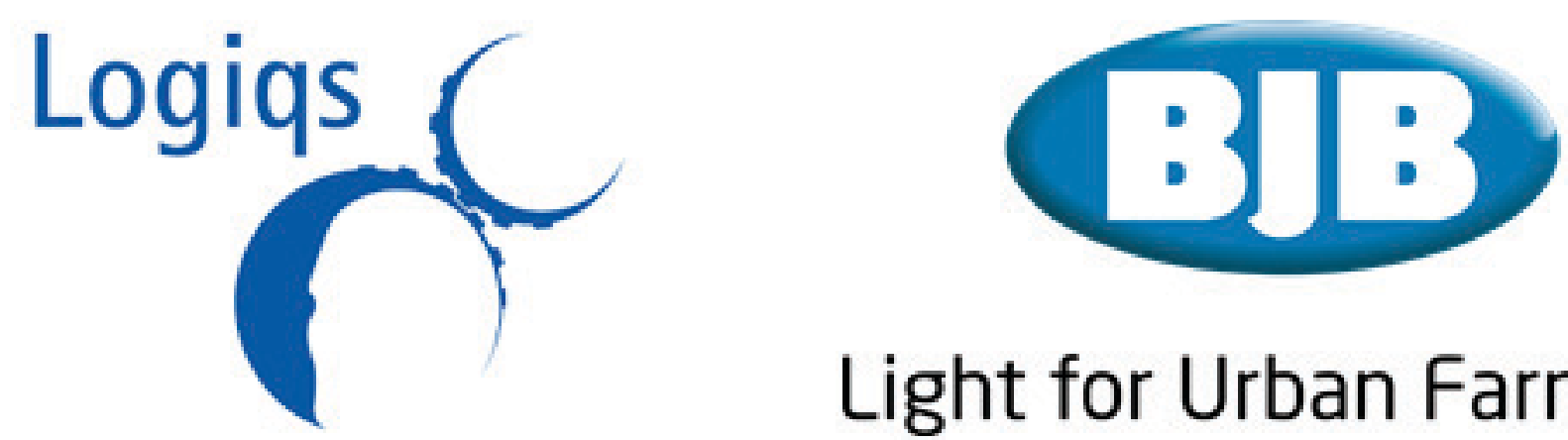

\section{Light for Urban Farming}

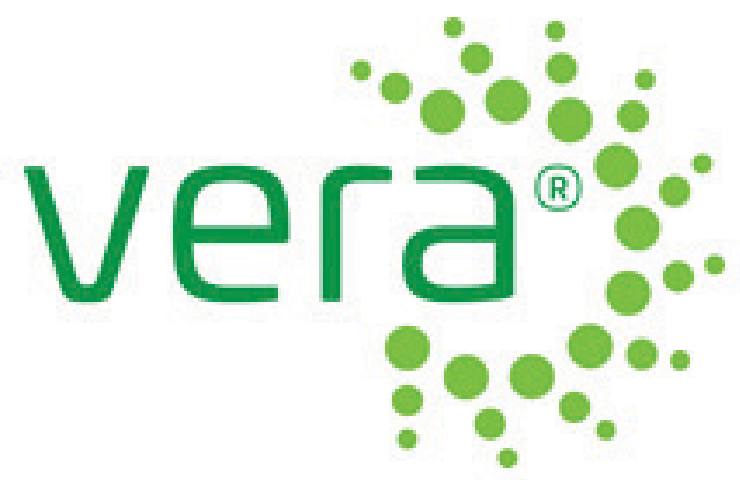

Nouryon

\section{Chelated} Micronutrients
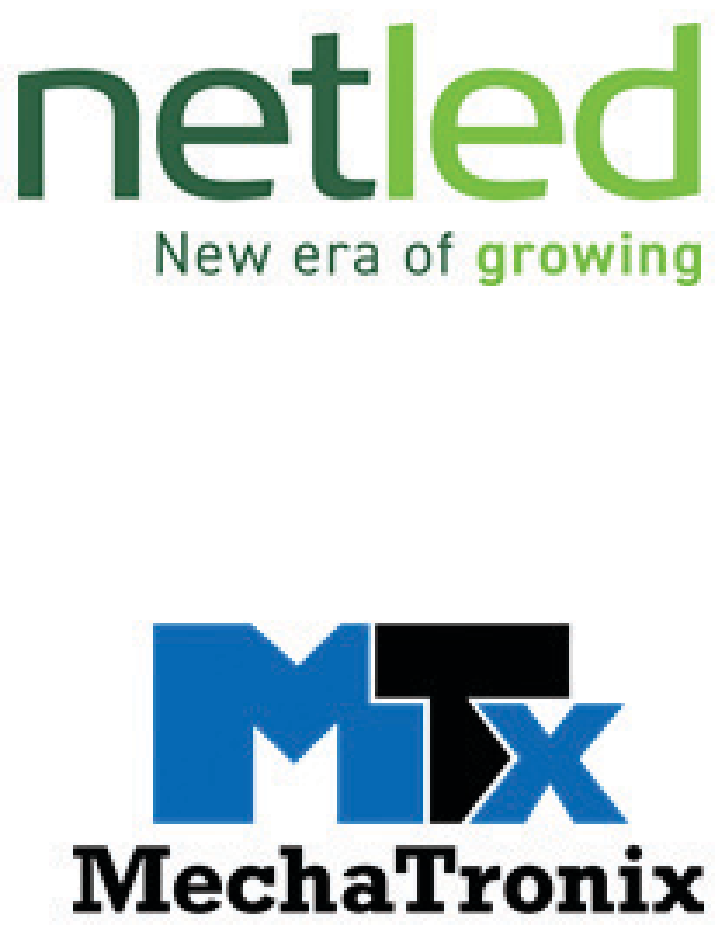

Fடㅁㅁய

$$
\text { F L U E N C E }
$$

